\title{
The Domestic Tax Code, Foreign Exchange Dynamics and Flow of Funds across Countries
}

\author{
Elli Kraizberg \\ Bar Ilan and Ariel University, Ramat Gan, Israel \\ Email: ekraizberg@gmail.com
}

How to cite this paper: Kraizberg, E. (2019) The Domestic Tax Code, Foreign Exchange Dynamics and Flow of Funds across Countries. Theoretical Economics Letters, 9, 1553-1568. https://doi.org/10.4236/tel.2019.95100

Received: January 28, 2019

Accepted: June 22, 2019

Published: June 25, 2019

Copyright ( 2019 by author(s) and Scientific Research Publishing Inc. This work is licensed under the Creative Commons Attribution International License (CC BY 4.0).

http://creativecommons.org/licenses/by/4.0/

(c) (i) Open Access

\begin{abstract}
Integrating tax methodology and foreign exchange rates dynamics, and utilizing Miller and Scholes [1] framework, we are able to derive a testable algorithm that identifies financial flow of funds across countries, which in turn leads to short term changes in exchange rates. In this model we are going to identify changes in the flow of funds, directed toward financial investments, lending or borrowing, between two countries, and thereby the short term changes in the foreign exchange rate that solely stems from expected changes in the tax codes. Thus, expected change in the foreign exchange rate becomes an endogenous variable, while the common view in the literature is that expected change in foreign exchange rates that differs from the market consensus is the trigger for flows of funds across countries. Alternatively, by using the above-mentioned algorithm, one can imply the market beliefs regarding expected changes in the tax code.
\end{abstract}

\section{Keywords}

Tax Code, Foreign Exchange, Capital Flows

\section{Introduction}

Integrating two different fields; taxation and foreign exchange dynamics, may lead to a resolution of the Fama's [2] "parity puzzle". We review the literature in the following order: first, the framework that is used in this study, foreign exchange theories, and finally the tax code that is related to the framework herein.

Miller and Scholes [1] developed a basic model that imbeds investment decisions and the domestic tax code. Their aim, though unrelated to the issue discussed in this paper, was to demonstrate that Miller's [3] presidential address, that has since become a key fundamental financial theorem, is correct in stating that even in a taxable world, the value of a firm is unaffected by how that firm is 
financed. This is true since an investor can choose a tax strategy depending on his/her tax status. Extending this framework to include cross-countries parameters requires that we will have a look at a different segment of the finance literature, in which the determination of foreign exchange rates is analyzed.

The two most well-known assertions in the academic international arena are the Parity Theorems that link changes in the foreign exchange rate to changes in inflation and interest rates. The Interest Rate Parity Theorem (IRP), also known as and the International Fisher Effect (IFE), or the Fisher Hypothesis, relies on Irving Fisher's [4] derivation of the relationship between nominal, real rates of interest and inflation. IRP asserts that the expected foreign exchange rate is a function of the ratio of the domestic and foreign nominal interest rates across countries. Specifically, in absence of international arbitrage opportunities, the expected return in one country should be equal to the expected return in a foreign country, denominated by the expected change in the foreign exchange rate. A foreign exchange forward contract is similarly priced, using the same assumption of absence of arbitrage opportunities. Since both, IFE expected exchange rate and forward price are of the same value, one must assume long-run zero-mean deviations between the expected exchange rate and the forward price.

The Purchasing Power Parity (PPP), attributed to Cassel [5], states that relative price changes across two trading countries over time determine the exchange rate between these two countries. Frenkel [6] developed the relative PPP and obtained estimates of respective coefficients that did not lead to clear cut rejection of the null hypothesis. Recently, Canarella, Miller and Pollard [7] confirm that inflation, usually measured as price differentials across any two trading countries, should be offset by exchange rate changes.

The theories have been tested in numerous studies, using various types of econometric techniques but the results are inconclusive. A large number of studies in the late 1970s failed to validate a significant PPP relationship mainly due to the non-stationarity of the residuals. Cumby and Obstfeld [8], Fama [2] and Levin and Lin (1992) have demonstrated that in the short-run, the IFE cannot be supported. This has led Fama [2] to question the theorem, labeling the lack of support as the "parity puzzle" and so did Bahmani-Oskooee, Kutan and Zahu [9] and many others.

Indwelling on the various econometric techniques, the following studies have found some support for the Parity Theorems: Aliber and Stickney [10], Edison [11], Manzur and Ariff [12], Edison and Melick [13] and Hill [14]. Shively [15] and Holmes [16] found evidence of a consistent PPP relationship. Recently, Hall, Hondroyiannis, Kenjegaliev, Swamy and Tavlas [17] support the parity but only in the long-run. Dimitriou and Simos [18] examine the weak and strong-form PPP over the period 2000-2012. Test results are in favor of weak-form, but not the strong-form PPP. Ho and Ariff [19] added non-parity factors, and Ariff and Zarei [20] explore why there is a lack of support especially for the price effect prediction of Purchasing Power Parity by applying newly introduced econome- 
tric tests. Tests have been conducted on the real exchange rates, cointegrated with real interest rates [21]-[26]. Mishkin [27], Johansen and Juselius [28], Edison and Melick [13] improve the results by considering the equality of real interest rates across a sample of major economies.

The current literature is under the opinion that there are additional factors that explain the behavior of foreign exchange rates. The Parity Theorems attribute the changes in exchange rates to changes in inflation and the rates of interest, while it is clear that the driving forces that affect changes in the foreign exchange rates are the flows of funds across countries ${ }^{1}$. Foreign currencies are continuously traded and their prices are set by demand and supply that are fueled by international flow of funds. If one assumes absence of international arbitrage opportunities, it is really immaterial where the flow of financial capital is originated, whether in one country or another. The accessibility to cash from capital markets has become easier because of new rules and regulations, leading to improved globalization of cash flows. Mark [31], Kim [32], and Rivera-Batiz [33] tested and established the direct relationship between the exchange rates and flow of funds across countries.

Clearly there is no consensus among academicians whether or not the predictions of these theorems hold empirically. However, the above studies employ the before-tax Parity Theorems. Obviously, flows of funds are motivated by the after-tax Parities, with or without "non-parity" factors, even if some of the participant, but not all, are tax exempted. More specifically, the after-tax scenario should integrate both, the existing tax code and the expected changes in the tax code, in both countries. In this paper, pointing out to a neglected area in the literature, we argue that very important factors that affect the flow of investment funds across countries are tax related: the difference in expected tax codes among various countries (such as the expected tax rates of the marginal market participant, or deductibility of foreign exchange losses, as indicated by Shapiro [34]), the Tax Treaty that may exist between each two countries, the level of enforcement (tax evasion and avoidance), thereby affecting both, the modeling of the IRP (See Appendix), the flow of funds across countries and the exchange rates. Levi [35] and Shapiro [34] recognize the role of expectations but only those that are related to the exchange rates, disregarding expectations of changes in the tax codes. The literature on international taxation mostly analyses the effects of ex-post changes in the tax code. Brean [36], for example, discussed the effect of the 1975-change in taxation of interest income between Canada and the US on the Parity Theorems (See Also Brooks-Stone [37] and Reiner and Soenen [38].

We develop an algorithm integrating expected tax changes, IRP and flow of ${ }^{1} \mathrm{~A}$ similar view, using country's reserves as the proxy for capital flow is given in Frankel and Rose [29]. The level of foreign exchange reserves of a country is a significant determinant of exchange rates. A country's currency is subject to movements as a result of unexpected changes in foreign reserves held by the central authority to service the trade bills arising from international trade and also to defend currency during crisis periods. See also Martínez [30], Marini and Piersanti (2003). 
funds across countries. Equation (7) derives the after-tax IRP which is slightly different than the one derived by Giddy [39] and Solnik et al. [40]. Unlike Shapiro [34], we conclude that the expected return across countries remains equalized, so that market participants are indifferent to investment/borrowing/lending in either country.

The focus of this paper is the expected changes in the tax codes. The tax codes are more dynamic than it seems. It is true that changes in tax codes are infrequent but the markets are constantly fueled by rumors and expectations regarding potential tax changes.

Avoiding convoluted analytical derivations, we make several simplified assumptions that can be relaxed. These assumptions will be described below.

\section{The Model}

Consider a world that consists of two countries with different and dynamic tax codes. Tax payers in each country can derive two types of income: earned income (such as labor income, ordinary business income) and income from financial markets. Income from financial markets can have three forms: dividends, short and long term capital gains and interest.

The tax code in each country is simple: different marginal tax rate on each type of income. There exists an investor at the margin whose tax rate in each category sets the market prices of financial instruments [3]. We make two alternative assumptions: individuals and firms may or may not offset earned incomes with financial losses (including foreign currency losses).

We adapt the Interest Rates Parity theory (IRP), known also as the International Fischer's hypothesis, IEF [4] stating that expected changes in the foreign exchange rate between the two countries are related to changes in nominal interest rates, or real interest rates and inflationary expectations. In absence of international arbitrage opportunities the IRP implies the foreign exchange forward rate as well, so we assume that the deviations of the expected exchange rate from the forward rate are distributed normally with a zero mean.

In the following model we are going to derive changes in the flow of funds between two countries and thereby the short term changes in the foreign exchange rate that solely stem from expected changes in the tax codes.

The fundamental assumptions underlying the model are as follows:

A1. Absence of arbitrage opportunities in the international financial markets.

A2. Effective tax rates are those of the investors at the margin.

A3. Financial losses may or may not be offset against earned or business income.

A4. Due taxes are payable continuously.

A5. There is a Tax Treaty between each two countries so that a taxpayer is liable for the highest tax liability between the two countries.

A6. Transaction costs are disregarded.

A7. Zero mean deviations between the foreign exchange rates and the corres- 
ponding forward prices.

\section{Notations:}

$Y_{i}$-Financial markets incomes in country $i$.

$W_{i}$-Total financial wealth in country $i$.

$y_{i}=Y_{i} / W_{i}$.

$y_{i j}$-Rate of return for investors from country $i$ in country $j$.

$S_{i}$-Total investment in equity in country $i, s_{i}=S_{i} / W_{i}$.

$s_{i}=S_{i} / W_{i}$.

$B_{i}$-Total investment in debt instruments in country $i$.

$d_{i}$-Dividend rate in country $i$.

$r_{i}$-Rate of interest in country $i$.

$g_{i}$-Expected capital gain on equity in country.

$\tau_{d i}$-Expected dividend tax rate of the marginal market participant in country $i$.

$\tau_{g i}$-Expected capital gain tax rate of the marginal market participant in country i.

$\tau_{r i}$-Expected interest income tax rate of the marginal market participant in country $i$.

$\tau^{*}-\max \left\{\tau_{i}, \tau_{j}\right\}$

$F_{i j}$-Foreign curent exchnage rate for country $i$ in terms of cuurency $j$.

$(1-\alpha)$-Portion of domestic financial wealth invested abroad.

$\sigma_{i}$-Standard deviation of rates of return in country $i$.

$\sigma_{i j}$-Standard deviation of rates of return for investors from country $i$ in coun$\operatorname{try} j$.

$\sigma_{i j}^{*}$-Overall standard deviation for investors from country $i$.

$\rho_{i j}$-Correlation coefficient between $i$ and $j$.

After-tax income, $Y_{i}$ derived in the financial markets in country $i$ is:

$$
Y_{i}=d_{i} S_{i}\left(1-\tau_{d i}\right)+g_{i} S_{i}\left(1-\tau_{g i}\right)+r_{i}\left(W_{i}-S_{i}\right)\left(1-\tau_{r i}\right)
$$

Denominating all variables by $W_{i}$ yields,

$$
y_{i}=d_{i} s_{i}\left(1-\tau_{d i}\right)+g_{i} s_{i}\left(1-\tau_{g i}\right)+r_{i}\left(1-s_{i}\right)\left(1-\tau_{r i}\right)
$$

Rearranging (2), separating tax and non-tax arguments, we create a linear equation:

$$
y_{i}=r_{i}\left(1-\tau_{r i}\right)+s_{i}\left\{\left(g_{i}+d_{i}-r_{i}\right)-\left(g_{i} \tau_{g i}+d_{i} \tau_{d i}-r_{i} \tau_{r i}\right)\right\}
$$

If $s_{i}=1$ then $y_{i}=s_{i}\left\{\left(g_{i}+d_{i}\right)-\left(g_{i} \tau_{g i}+d_{i} \tau_{d i}\right)\right\}$.

If $s_{i}>1$ a tax payer is a net borrower of investment funds.

In a tax-free economy,

$$
y_{i}=r_{i}+s_{i}\left\{\left(g_{i}+d_{i}-r_{i}\right)\right\}
$$

$g_{i} \tau_{g i}$, the capital gain tax may be payable only upon realization of the gain, thus $g_{i} \tau_{g i}$ can viewed as the present value of these taxes. Theoretically, these taxes can be postponed indefinitely, therefore have a zero present value [41]. In 
any event, if long term capital gains are not taxable as current income (income reported annually), then there exists a critical $s_{i}^{*}, s_{i}>1$ where financial current income rate of return, $y_{i}$, is zero, since a taxpayer can fully offset incomes with interest paid in the financial markets:

$$
s_{i}^{*}=\frac{r_{i} \tau_{r i}}{\left(r_{i} \tau_{r i}-d_{i} \tau_{d i}\right)}>1
$$

If a tax payer can offset current financial losses toward earned or business income, then if $s_{i}>s_{i}^{*}$ financial losses are deductible toward earned income. If the tax code does not allow offset (for individual taxpayers in most countries around the globe) then (3) becomes,

$$
y_{i}=r_{i}\left(1-\tau_{r i}\right)+\left\{\min \left(s_{i}^{*}, s_{i}\right)\right\}\left\{\left(d_{i}-r_{i}\right)-\left(d_{i} \tau_{d i}-r_{i} \tau_{r i}\right)\right\}+s_{i} g_{i}\left(1-\tau_{g i}\right)
$$

The tax code for individuals in the US, for example, is:

$$
y_{i}=r_{i}\left(1-\tau_{r i}\right)+\left\{\min \left(\left(s_{i}^{*}+\frac{15000}{W_{i}}\right), s_{i}\right)\right\}\left\{\left(g_{i}+d_{i}-r_{i}\right)-\left(g_{i} \tau_{g i}+d_{i} \tau_{d i}-r_{i} \tau_{r i}\right)\right\}
$$

Graphically, the expected rate of domestic financial return is described in Figure 1:

The current expected foreign exchange rate in the future in country $i$ using after-tax IRP (deleting time dimension for simplicity of exposition):

$$
E F_{i j}=F_{i j} \frac{1+r_{i}\left(1-\tau_{r i}\right)}{\left[1+r_{j}\left(1-\tau_{r j}\right)\right]\left[1-\tau_{g i}\left(1+r_{i}\left(1-\tau_{r i}\right)\right)\right]}
$$

(See proof for this version of the after-tax IRP in Appendix).

The literature attributes changes in the expected foreign exchange rate to solely changes in the interest rates in each country. The common after-tax IRP, which relies on the assumption of absence of international arbitrage opportunities, implicitly assumes a constant tax code.

A Tax Treaty between the two countries may dictate that a tax liability is set solely based on the source of incomes (location wise). We will assume, however, that there is a Tax Treaty between the two countries and investors in a foreign country would pay the highest tax rate between the two countries. Assume further that all financial losses are symmetrically deductible.

Thus, investors in country $i$, who invest $(1-\alpha)$ of their wealth in country $j$ would expect the following return (given the assumed Tax Treaty between the two countries):

$$
\begin{aligned}
y_{i j}= & \alpha y_{i}+(1-\alpha)\left\{d_{j} s_{i j}\left(1-\tau_{d}^{*}\right)\left(\frac{E F_{i j}}{F_{i j}}\right)+\left(\left(1+g_{j}\right)\left(\frac{E F_{i j}}{F_{i j}}\right)-1\right) s_{i j}\left(1-\tau_{g}^{*}\right)\right. \\
& \left.+r_{j}\left(1-s_{i j}\right)\left(1-\tau_{r}^{*}\right)\left(\frac{E F_{i j}}{F_{i j}}\right)\right\}
\end{aligned}
$$

where $\tau_{d}^{*}, \tau_{g}^{*}, \tau_{r}^{*}$ are the highest expected tax rates between the two countries? The initial choice of the control variable $s$ in each country is given exogenously. 


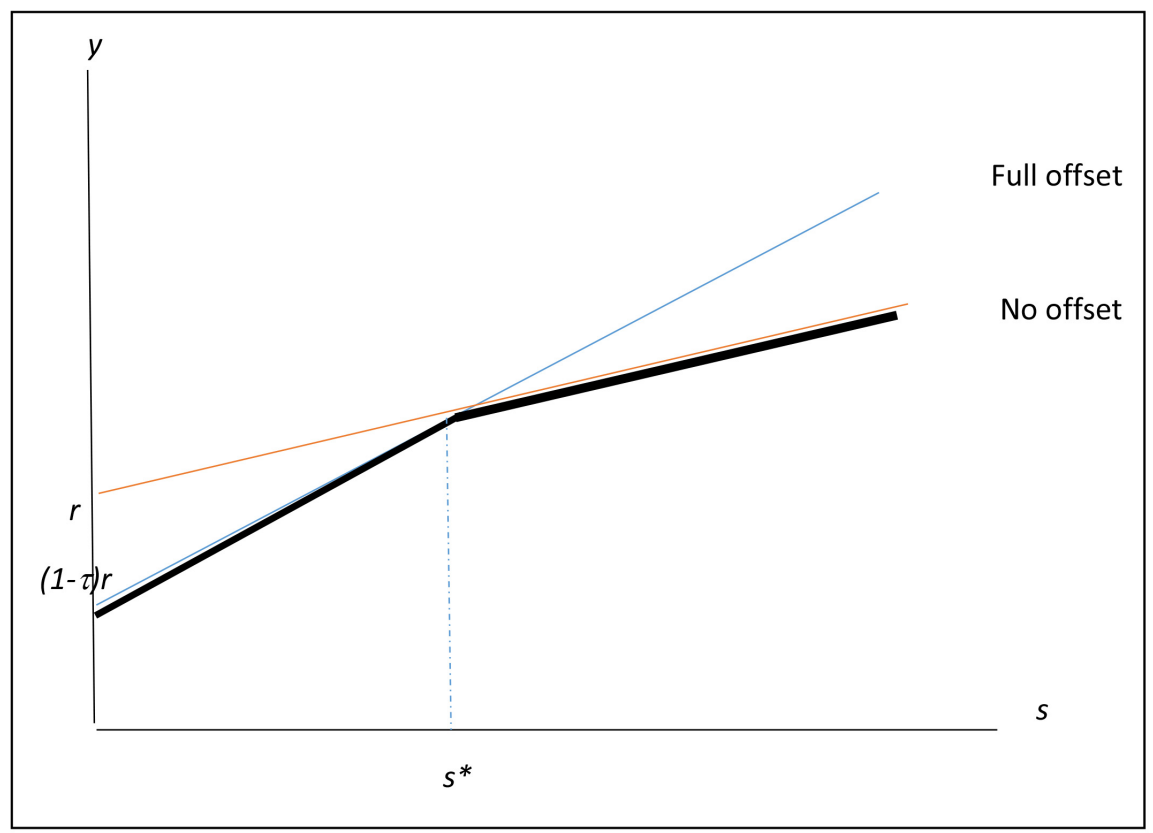

Figure 1. The blue line describes after-tax return and the orange line is before-tax return. The expected financial return of a tax payer starts at $(1-\tau) r$ when $s=0$ (the segment where the black and the blue lines coincide). Then, at $s^{*}$ the net financial income becomes negative but if the tax payer may not offset financial losses with earned income, the expected return moves along the orange line which describes the before-tax expected rate of return.

Initially and without loss of generality, we assume that the investors in country $i$ choose the same initial $s$ for investment in their own country and in country $j$, (i.e. $s_{i}=s_{i j}$ and similarly $s_{j}=s_{j i}$ ).

Thus (8) can be rewritten (reflecting investment in the foreign country) as,

$$
\begin{aligned}
y_{i j}= & {\left[\alpha r_{i}\left(1-\tau_{r i}\right)+(1-\alpha) r_{j}\left(1-\tau_{r}^{*}\right)\left(\frac{E F_{i j}}{F_{i j}}\right)-(1-\alpha)\left(\frac{E F_{i j}}{F_{i j}}-1\right)\left(1-\tau_{g i}\right)\right] } \\
& +s_{i}\left\{\alpha\left[\left(g_{i}+d_{i}-r_{i}\right)-\left(\tau_{d i}+\tau_{g i}-\tau_{r i}\right)\right]\right. \\
& \left.+(1-\alpha)\left(\frac{E F_{i j}}{F_{i j}}\right)\left[\left(g_{j}+d_{j}-r_{j}\right)-\left(\tau_{d j}^{*}+\tau_{g j}^{*}-\tau_{r j}^{*}\right)\right]\right\}
\end{aligned}
$$

Note that the third term in line 1 of (9) reflects capital gain/loss tax from the expected change in the value of the foreign currency, payable in own country as a capital gain/loss tax upon realization. This tax is due and payable in addition to the taxes on exchange rate gain/loss due to the interest, dividends and capital gain from equity.

We also assume zero correlation between expected change in interest rates and expected changes in the tax code ${ }^{2}$.

If the tax code is expected to be changed, then, even well before it will take ef${ }^{2}$ Though we could implement an assumption of non-zero correlation, it will make the analysis much more complicated and would divert the focus to an unrelated issue. 
fect, investors are likely to shift funds across countries. These flows of funds are likely to trigger a change in the exchange rate between the two countries.

First, assume that a certain tax code $\tau$ in either country is expected to be changed. This would trivially change the expected return, which will call for a change in $\alpha$. More specifically,

$$
\frac{\partial \alpha_{i}}{\partial y_{i}} \frac{\partial y_{i}}{\partial \tau_{i}} \mathrm{~d} \tau \text { or } \frac{\partial \alpha_{j}}{\partial y_{j i}} \frac{\partial y_{j i}}{\partial \tau_{i}} \mathrm{~d} \tau_{i}
$$

(10) represents the expected changes in county $i$ and $j$ respectively. Deriving $\frac{\partial y_{i j}}{\partial \tau}$, which is always negative, is trivial and will be shown below. Establishing the exact form of $\frac{\partial \alpha_{i}}{\partial y_{i j}}$ requires separate modelling (see below in Section 3). At this stage we identify the sign. If the expected change in the tax code is in country $i,\left(\tau=\tau_{i}\right)$, than,

$$
\frac{\partial \alpha_{i}}{\partial y_{i j}} \frac{\partial y_{i j}}{\partial \tau_{i}} \mathrm{~d} \tau_{i} \geq 0 \text { and } \frac{\partial\left(1-\alpha_{j}\right)}{\partial y_{j i}} \frac{\partial y_{j i}}{\partial \tau_{i}} \mathrm{~d} \tau_{i} \geq 0
$$

If the expected change in the tax code is in country $j,\left(\tau=\tau_{j}\right)$, than

$$
\frac{\partial\left(1-\alpha_{i}\right)}{\partial y_{i j}} \frac{\partial y_{i j}}{\partial \tau_{j}} \mathrm{~d} \tau_{j} \geq 0 \text { and } \frac{\partial \alpha_{j}}{\partial y_{j}} \frac{\partial y_{j}}{\partial \tau_{j}} \mathrm{~d} \tau_{j} \geq 0
$$

\section{The Flow of Funds across Countries}

Under the assumption of free flow of funds and no transaction costs, the flow of funds to country $i$ that stems solely from the expected change in the tax code in county $j$, is:

$$
\left[W_{i} \frac{\partial \alpha_{i}}{\partial y_{i j}} \frac{\partial y_{i j}}{\partial \tau_{j}}-W_{j} \frac{\partial \alpha_{j}}{\partial y_{j i}} \frac{\partial y_{j i}}{\partial \tau_{j}}\right] \mathrm{d} \tau_{j}
$$

where the first term represents flow of funds by investors from country $i$, to or from abroad, and the second term is the foreign flow, to or from country $i$. Similarly if the tax code in country $i$ is expected to change:

$$
\left[-W_{i} \frac{\partial \alpha_{i}}{\partial y_{i j}} \frac{\partial y_{i j}}{\partial \tau_{i}}+W_{j} \frac{\partial \alpha_{j}}{\partial y_{j i}} \frac{\partial y_{j i}}{\partial \tau_{i}}\right] \mathrm{d} \tau_{i}
$$

Consider a scenario in which the Tax Treaty calls for tax liabilities that are solely based on the source of incomes (location wise). There are no international transaction costs and free flow of funds between countries. Full offset of earned and financial incomes is allowed and all losses are deductible, within each income category and across categories. As a particular case, assume that the capital gain tax rate in country $j$ is expected to change.

Since the expected income (9) is a function of three key variables:

$$
y_{i j}=f\left\{\alpha\left(y_{i j}\left(\tau_{g j}\right)\right), \tau_{g j},\left(E F_{i j} / F_{i j}\right)\right\}
$$

${ }^{3}$ Including foreign exchange rate losses. 
Then

$$
\frac{\partial y_{i j}}{\partial \tau_{g j}} \mathrm{~d} \tau_{g j}=\left[\frac{\partial f}{\partial \alpha} \frac{\partial \alpha}{\partial y_{i j}} \frac{\partial y_{i j}}{\partial \tau_{g j}}+\frac{\partial f}{\partial \tau_{g j}}+\frac{\partial f}{\partial\left(E F_{i j} / F_{i j}\right)} \frac{\partial\left(E F_{i j} / F_{i j}\right)}{\partial \tau_{g j}}\right] \mathrm{d} \tau_{g j}
$$

Rearranging (15) yields,

$$
\frac{\partial y_{i j}}{\partial \tau_{g j}}=\frac{\frac{\partial f}{\partial \tau_{g j}}+\frac{\partial f}{\partial\left(E F_{i j} / F_{i j}\right)} \frac{\partial\left(E F_{i j} / F_{i j}\right)}{\partial \tau_{g j}}}{1-\frac{\partial f}{\partial \alpha} \frac{\partial \alpha}{\partial y_{i j}}}
$$

The flow of funds, to or from country $i$, using (14) would look like,

$$
\begin{gathered}
{\left[W_{i} \frac{\partial_{i}}{\partial y_{i j}}\left\{\frac{\frac{\partial f_{i}}{\partial \tau_{g j}}+\frac{\partial f_{i}}{\partial\left(E F_{i j} / F_{i j}\right)} \frac{\partial\left(E F_{i j} / F_{i j}\right)}{\partial \tau_{g j}}}{1-\frac{\partial f_{i}}{\partial \alpha} \frac{\partial \alpha}{\partial y_{i j}}}\right\}\right.} \\
-W_{j} \frac{\partial_{j}}{\partial y_{j i}}\left\{\frac{\frac{\partial f_{j}}{\partial \tau_{g j}}+\frac{\partial f_{j}}{\partial\left(E F_{j i} / F_{j i}\right)} \frac{\partial\left(E F_{j i} / F_{j i}\right)}{\partial \tau_{g j}}}{1-\frac{\partial f_{j}}{\partial \alpha} \frac{\partial \alpha}{\partial y_{j i}}}\right\} \mathrm{d} \tau_{g j}
\end{gathered}
$$

where

$$
\begin{aligned}
\frac{\partial f_{i}}{\partial \alpha_{i}}= & \left.r_{i}\left(1-\tau_{r i}\right)-r_{j}\left(1-\tau_{r}^{*}\right)\left(\frac{E F_{i j}}{F_{i j}}\right)+\left(\frac{E F_{i j}}{F_{i j}}-1\right)\left(1-\tau_{g i}\right)\right] \\
& +s_{i}\left\{\left[\left(g_{i}+d_{i}-r_{i}\right)-\left(\tau_{d i}+\tau_{g i}-\tau_{r i}\right)\right] \quad \text { and similarly for } \frac{\partial f_{j}}{\partial \alpha_{j}}\right. \\
& \left.-\left(\frac{E F_{i j}}{F_{i j}}\right)\left[\left(g_{j}+d_{j}-r_{j}\right)-\left(\tau_{d j}^{*}+\tau_{g j}^{*}-\tau_{r j}^{*}\right)\right]\right\}
\end{aligned}
$$

And

$$
\frac{\partial f_{i}}{\partial \tau_{g j}}=\left[(1-\alpha)\left(\frac{E F_{i j}}{F_{i j}}-1\right)\right]+s_{i}\left\{-\alpha+(1-\alpha)\left(\frac{E F_{i j}}{F_{i j}}\right)\right\} \text { Similarly for } \frac{\partial f_{j}}{\partial \tau_{g j}}
$$

where $\frac{\partial \frac{E F_{i j}}{F_{i j}}}{\partial \tau_{g j}}=\frac{1}{\frac{\partial \frac{E F_{j i}}{F_{j i}}}{\partial \tau_{g j}}}$, and. the change in the expected foreign exchange rate

in country $i$ due to expected change in the capital gain tax rate in country $j$, is, (using (7)), 


$$
\frac{\partial \frac{E F_{i j}}{F_{i j}}}{\partial \tau_{g j}}=\frac{\left[1+r_{i}\left(1-\tau_{r i}\right)\right]^{2}}{\left[1+r_{j}\left(1-\tau_{r j}\right)\right]\left[1-\tau_{g i}\left(1+r_{i}\left(1-\tau_{r i}\right)\right)\right]^{2}}
$$

If we wish to test this model empirically, one has to derive $\frac{\partial \alpha}{\partial y_{j i}}$, using basic finance modeling of risk-return tradeoff, in particular, the Separation Theorem ${ }^{4}$ of perfectly diversified market portfolios. Though this derivation is somewhat beyond the scope of this paper, we will lay down the framework for solving $\frac{\partial \alpha}{\partial y_{j i}}$. Specifically, we will show a simplified case through which an analytical argument can be established.

Consider on example of a two-asset case in which an investor allocates his financial wealth between two portfolios; $\alpha_{i}$ of which in a domestic portfolio yielding a rate of return as in (3) and associated with a risk, $\sigma_{i}$, measured by the standard deviation of the rates of return, and $\left(1-\alpha_{i}\right)$ of which in a similar portfolio in country $j$, associated with risk of $\sigma_{i j}$.

$$
\sigma_{i j}=\left(\sigma_{j}^{2}+\sigma_{F}^{2}+\frac{2 \rho_{j F}}{\sigma_{j} \sigma_{F}}\right)^{0.5}
$$

where $\sigma_{j}$ is the standard deviation of the rates of return in country $j, \sigma_{F}$ is the standard deviation of the changes in the exchange rate between the two countries, and $\rho_{j F}$ is the correlation coefficient between the returns in country $j$ and the exchange rate. The coefficient $\rho_{j F}$ is fairly high, positive from an investor $i$ s point of view and can be measured empirically.

The overall risk of the two-asset diversified portfolio is $\sigma_{i j}^{*},\left(\alpha=\alpha_{i}\right)$

$$
\sigma_{i j}^{*}=\left\{\alpha^{2} \sigma_{i}^{2}+(1-\alpha)^{2}\left(\sigma_{j}^{2}+\sigma_{F}^{2}+\frac{2 \rho_{j F}}{\sigma_{j} \sigma_{F}}\right)+\frac{2 \alpha(1-\alpha) \rho_{i j}}{\left[\sigma_{i}\left(\sigma_{j}^{2}+\sigma_{F}^{2}+\frac{2 \rho_{j F}}{\sigma_{j} \sigma_{F}}\right)\right]}\right\}^{0.5}
$$

Suppose that the capital gain tax in country $j, \tau_{g j}$ is expected to be reduced, recalling the assumption regarding the Tax Treaty, that if $\frac{\partial \tau^{*}}{\partial \tau_{i}}=0$ or $\frac{\partial \tau^{*}}{\partial \tau_{j}}=0$ i.e., a change in tax rate in one country does not reach the maximum tax rate, the initial equilibrium is unaffected and no flow of funds is triggered due to the expected change in the tax code.

It is not unlikely that statutory reduction in $\tau_{g j}$ will cause the effective tax rate to bounce back due to investors' decision to shorten holding periods, so that the present value of the tax rate would increase [42], but disregarding this possi${ }^{4}$ Identified by I. Fisher and subsequently has been applied to the CAPM framework. It states that investment decisions in risky assets are independent of preference, where the latter is set by the choice of market portfolio and the riskless asset. 
bility, the expected statutory reduction in $\tau_{g j}$ would improve the after-tax return in country $j$. Investors from country $i$ are likely to increase their foreign investment portion $(1-\alpha)$, thus $\frac{\partial \alpha}{\partial y_{i j}}<0$.

Specifically, consider the following assumption: investors in country $i$ increase $(1-\alpha)$ but keep the overall level of risk on their portfolio constant by changing $s_{i j}$, i.e., their choice of equity holdings in country $j$. Figure 2 will explain how this can be done.

Define $\sigma_{i j}^{*}=f\left(\sigma_{i}, \sigma_{j}, s_{i} ; \alpha, s_{j}\right)$ as the overall risk level, investors of country $i$ are exposed to. If the overall risk level remains the same, it must be true that, (simplifying notations, $\alpha_{i}=\alpha$ and $s_{j}=s_{i j}$ )

$$
\frac{\partial f}{\partial \alpha} \mathrm{d} \alpha+\frac{\partial f}{\partial s_{j}} \mathrm{~d} s_{j}+\frac{\partial^{2} f}{\partial \alpha \partial s_{j}} \mathrm{~d} \alpha \mathrm{d} s_{j}=0
$$

Neglecting the third term, then for any given $\mathrm{d} \alpha$, there exists a unique $\mathrm{d} s_{j}$. Thus one can choose a pair of $\mathrm{d} \alpha$ and $\mathrm{d} s_{j}$ that maximizes the change in the overall return. Analytically, from (21) it is implied that,

$$
\mathrm{d} s_{j}=\mathrm{d} \alpha \frac{\frac{\partial f}{\partial \alpha}}{\frac{\partial f}{\partial s_{j}}}
$$

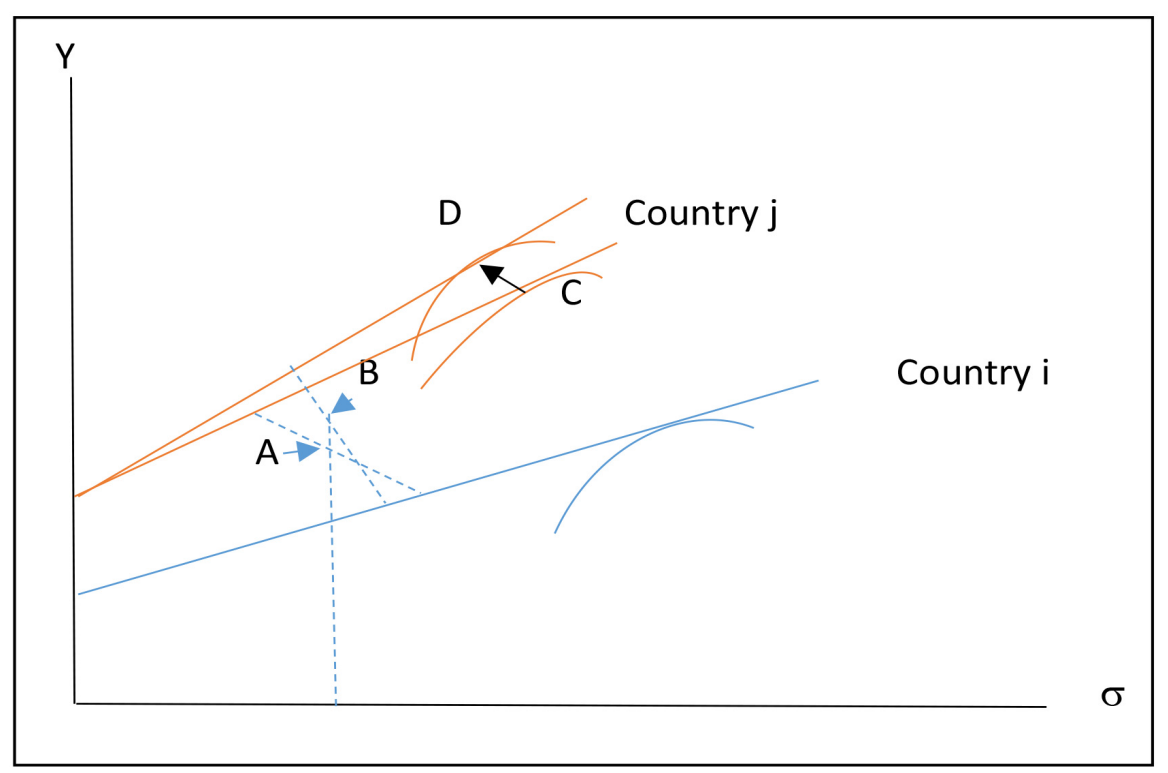

Figure 2. The curves represent the efficient opportunity sets in each country. The lines represent Equation (3) (see Figure 1). The tangencies of the opportunity sets to the return line represent the market equity-portfolio in each country. If the capital gain tax in country $j$ is expected to be reduced the tangency in this country goes up from point $\mathrm{C}$ to D. The original linear combination given $\alpha$ (Equation (8)) (dotted line) of investors in country $i$ is point A and they move to point B by changing $s$ and $\alpha$ (Equation (21) such that the overall risk level, measure on the horizontal axis, remains constant (B is exactly above A, i.e. the same risk level). 
From (20) and given that $\sigma_{i}^{2}=s_{i}^{2} \sigma_{s}^{2}$ the partial derivatives in (22) are,

$$
\begin{gathered}
\frac{\partial f}{\partial \alpha}=\left\{\alpha \sigma_{s_{i}}^{2}-\alpha\left(s_{j}^{2} \sigma_{s_{j}}^{2}+\sigma_{F}^{2}+\frac{2 \rho_{s_{j} F}}{s_{j} \sigma_{s_{j}} \sigma_{F}}\right)+\frac{(1-2 \alpha) \rho_{s_{i} s_{j}}}{\left[s_{i} \sigma_{s_{i}}\left(s_{j}^{2} \sigma_{s_{j}}^{2}+\sigma_{F}^{2}+\frac{2 \rho_{s_{j} F}}{s_{j} \sigma_{s_{j}} \sigma_{F}}\right)\right]}\right\} \text { and } \\
\frac{\partial f}{\partial s_{j}}=\left\{(1-\alpha)^{2}\left(s_{j} \sigma_{s_{j}}^{2}+\sigma_{F}^{2}+\frac{2 \rho_{s_{j} F}}{\sigma_{s_{j}} \sigma_{F}}\right)+\frac{2 \alpha(1-\alpha) \rho_{s_{i} s_{j}}}{\left.\left[\sigma_{i}\left(s_{j} \sigma_{s_{j}}^{2}+\sigma_{F}^{2}+\frac{2 \rho_{s_{j} F}}{\sigma_{s_{j}} \sigma_{F}}\right)\right]\right\}}\right\}
\end{gathered}
$$

Then, maximizing the return given all possible pairs of $\mathrm{d} \alpha$ and $\mathrm{d} s_{j}$, and re-implementing the assumption about the more common Tax Treaty, yields,

$$
\begin{aligned}
M A X_{\mathrm{d} \alpha} y_{i j} & M_{\mathrm{d} \alpha}\left[\mathrm{d} r_{i}\left(1-\tau_{r i}\right)+(1-\mathrm{d} \alpha) r_{j}\left(1-\tau_{r}^{*}\right)\left(\frac{E F_{i j}}{F_{i j}}\right)\right. \\
& \left.-(1-\mathrm{d} \alpha)\left(\frac{E F_{i j}}{F_{i j}}-1\right)\left(1-\tau_{g i}\right)\right]+s_{i} \mathrm{~d} \alpha\left[\left(g_{i}+d_{i}-r_{i}\right)-\left(\tau_{d i}+\tau_{g i}-\tau_{r i}\right)\right] \\
& +\left[\mathrm{d} \alpha \frac{\frac{\partial f}{\partial f}}{\frac{\partial f}{\partial s_{j}}}\right]\left\{(1-\mathrm{d} \alpha)\left(\frac{E F_{i j}}{F_{i j}}\right)\left[\left(g_{j}+d_{j}-r_{j}\right)-\left(\tau_{d j}^{*}+d \tau_{g j}^{*}-\tau_{r j}^{*}\right)\right]\right\}
\end{aligned}
$$

All the above parameters can be measured empirically so that a numeric solution can be obtained. The solution above can change if we modify some of the assumptions regarding the specific tax codes, such as the offset of finical losses with earned income, deductibility of foreign currency losses, short term vs. long terms capital gain rates, etc. Market barriers such as transaction costs may also affect the solution.

\section{Conclusions}

Flow of funds across countries sets the demand and supply of foreign currencies, and thereby sets the short term behavior of the exchange rates. One possible key factor that may affect the flow of funds is the expected changes in the tax codes, rather than just the actual ones. We derived a testable algorithm that is based on parameters that can be empirically estimated. Alternatively, by using the above argument and assuming market efficiency, one can imply market expectations regarding expected changes in the tax code.

The issue raised in this paper may be generalized further. First, the various assumptions can be relaxed in order to establish a more general argument, either in a form of sets of tax rules, or in terms of various possible cases. More impor- 
tantly, assumption A7 should be relaxed and investigated further: while the forward price must be a function of current interest rates (by arbitrage), the expected exchange rates may behave differently due to expected changes in the flow of funds. In fact, the forward rate and the exchange rate can move in the opposite direction. For example, the forward rate is expected to decline to an expected increase in the foreign rate of interest while the expected exchange rate is expected to rise due to an expected net positive flow into the foreign country, fueled by the expected rise in the foreign rate of interest.

\section{Conflicts of Interest}

The author declares no conflicts of interest regarding the publication of this paper.

\section{References}

[1] Miller, M.H. and Scholes, S.M. (1978) Dividend and Taxes. Journal of Financial Economics, 6, 333-364. https://doi.org/10.1016/0304-405X(78)90009-0

[2] Fama, E.F. (1984) Forward and Spot Exchange Rates. Journal of Monetary Economics, 14, 319-338. https://doi.org/10.1016/0304-3932(84)90046-1

[3] Miller, H.M. (1977) Debt and Taxes. The Journal of Finance, 32, 261-275. https://doi.org/10.1111/j.1540-6261.1977.tb03267.x

[4] Fisher, I. (1930) The Theory of Interest. Macmillan, New York.

[5] Cassel, G. (1918) Abnormal Deviations in International Exchanges. The Economic Journal, 28, 413-415. https://doi.org/10.2307/2223329

[6] Frenkel, J.A. (1976) A Monetary Approach to the Exchange Rate: Doctrinal Aspects and Empirical Evidence. The Scandinavian Journal of Economics, 78, 200-224. https://doi.org/10.2307/3439924

[7] Canarella, G., Miller, S.M. and Pollard, S.K. (2014) Purchasing Power Parity between the UK and Germany: The Euro Era. Open Economics Review, 25, 677-699. https://doi.org/10.1007/s11079-014-9309-9

[8] Cumby, R.E. and Obstfeld, M. (1981) A Note on Exchange-Rate Expectations and Nominal Interest Differentials: A Test of the Fisher Hypothesis. The Journal of Finance, 36, 697-703. https://doi.org/10.1111/j.1540-6261.1981.tb00654.x

[9] Bahmani-Oskooee, M., Kutan, A.M. and Zhou, S. (2009) Towards Solving the PPP Puzzle: Evidence from 113 Countries. Applied Economics, 41, 3057-3066. https://doi.org/10.1080/00036840701367648

[10] Aliber, R.Z. and Stickney, C.P. (1975) Accounting Measures of Foreign Exchange Exposure: The Long and Short of It. The Accounting Review, 50, 44-57.

[11] Edison, H.J. (1987) Purchasing Power Parity in the Long Run: A Test of the Dollar/Pound Exchange Rate (1890-1978). Journal of Money, Credit and Banking, 19, 376-387. https://doi.org/10.2307/1992083

[12] Manzur, M. and Ariff, M. (1995) Purchasing Power Parity: New Methods and Extensions. Applied Financial Economics, 5, 19-26. https://doi.org/10.1080/758527667

[13] Edison, H.J. and Melick, W.R. (1999) Alternative Approaches to Real Exchange Rates and Real Interest Rates: Three Up and Three Down. International Journal of Finance \& Economics, 4, 93-111. https://doi.org/10.1002/(SICI)1099-1158(199904)4:2<93::AID-IJFE93>3.0.CO;2-R 
[14] Hill, C.H. (2004) International Business: Competing in the Global Marketplace. 5th Edition, McGraw-Hill, Pennsylvania, PA.

[15] Shively, P.A. (2001) A Test of Long-Run Purchasing Power Parity. Economic Letters, 73, 201-205. https://doi.org/10.1016/S0165-1765(01)00488-8

[16] Holmes, M.J. (2008) Real Exchange Rate Stationarity in Latin America and Relative Purchasing Power Parity: A Regime Switching Approach. Open Economic Review, 19, 261-275. https://doi.org/10.1007/s11079-007-9020-1

[17] Hall, S.G., Hondroyiannis, G., Kenjegaliev, A., Swamy, P. and Tavlas, G.S. (2013) Is the Relationship between Prices and Exchange Rates Homogeneous? Journal of International Money and Finance, 37, 411-438. https://doi.org/10.1016/j.jimonfin.2013.06.014

[18] Dimitriou, D. and Simos, T. (2013) Testing Purchasing Power Parity for Japan and the US: A Structural-Break Approach. Japan and the World Economy, 28, 53-59. https://doi.org/10.1016/j.japwor.2013.07.001

[19] Ho, C.S.F. and Ariff, M. (2012) Time to Equilibrium in Exchange Rates: G-10 and Eastern European Economies. Global Finance Journal, 23, 94-107.

https://doi.org/10.1016/j.gfj.2012.03.002

[20] Ariff, M. and Zarei, A. (2016) Exchange Rate Behavior of Canada, Japan, the United Kingdom and the United States. Open Economic Review, 27, 341-357. https://doi.org/10.1007/s11079-015-9372-x

[21] Meese, R. and Rogoff, K. (1988) Was It Real? The Exchange Rate-Interest Differential Relation over the Modern Floating-Rate Period. The Journal of Finance, 43, 933-948. https://doi.org/10.1111/j.1540-6261.1988.tb02613.x

[22] Edison, H.J. and Pauls, B.D. (1993) A Re-Assessment of the Relationship between Real Exchange Rates and Real Interest Rates: 1974-1990. Journal of Monetary Economics, 31, 165-187. https://doi.org/10.1016/0304-3932(93)90043-F

[23] Throop, A.W. (1993) A Generalized Uncovered Interest Parity Model of Exchange Rates. Economic Review, 2, 3-16.

[24] Rogoff, K. (1996) The Purchasing Power Parity Puzzle. Journal of Economic Literature, 34, 647-668.

[25] Lothian, J.R. and Taylor, M.P. (1996) Real Exchange Rate Behavior: The Recent Float from the Perspective of the Past Two Centuries. Journal of Political Economy, 104, 488-509. https://doi.org/10.1086/262031

[26] Mollick, A.V. (1999) The Real Exchange Rate in Brazil Mean Reversion or Random Walk in the Long Run? International Review of Economics and Finance, 8, 115-126. https://doi.org/10.1016/S1059-0560(99)00009-X

[27] Mishkin, F.S. (1984) Are Real Interest Rates Equal across Countries? An Empirical Investigation of International Parity Conditions. The Journal of Finance, 39, 1345-1357. https://doi.org/10.1111/j.1540-6261.1984.tb04911.x

[28] Johansen, S.R. and Juselius, K. (1992) Testing Structural Hypotheses in a Multivariate Cointegration Analysis of the PPP and the UIP for UK. Journal of Economics, 53, 211-244. https://doi.org/10.1016/0304-4076(92)90086-7

[29] Frankel, J.A. and Rose, A.K. (1996) Currency Crashes in Emerging Markets: An Empirical Treatment. Journal of International Economics, 41, 351-366. https://doi.org/10.1016/S0022-1996(96)01441-9

[30] Martínez, J. (1999) Mexico's Balance of Payments and Exchange Rates: A Cointegration Analysis. The North American Journal of Economics and Finance, 10, 401-421. https://doi.org/10.1016/S1062-9408(99)00031-5 
[31] Mark, N.C. (1985) Some Evidence on the International Inequality of Real Interest Rates. Journal of International Money and Finance, 4, 189-208. https://doi.org/10.1016/0261-5606(85)90043-9

[32] Kim, Y. (2000) Causes of Capital Flows in Developing Countries. Journal of International Money and Finance, 19, 235-253. https://doi.org/10.1016/S0261-5606(00)00001-2

[33] Rivera-Batiz, F.L. and Rivera-Batiz, L.A. (2001) International Financial Liberalization, Capital Flows, and Exchange Rate Regimes: An Introduction. Review of International Economics, 9, 573-584. https://doi.org/10.1111/1467-9396.00300

[34] Shapiro, A.C. (1984) The Impact of Taxation on the Currency-of-Denomination Decision for Long Term Borrowing and Lending. Journal of International Business Studies, 15, 15-25. https://doi.org/10.1057/palgrave.jibs.8490468

[35] Levy, M.D. (1977) Taxation and Abnormal International Capital Flows. Journal of Political Economy, 85, 635-646. https://doi.org/10.1086/260588

[36] Brean, D.J.S. (1984) The Wedge of the Withholding Tax-International Portfolio Capital. National Tax Journal, 37, 239-247.

[37] Brooks-Stone, G. (1985) An Empirical Analysis of the Impact of Differential Tax Rates and Transaction Costs upon Covered Interest-Rate-Parity. Ph.D. Dissertation, Ohio State University, Columbus, $\mathrm{OH}$.

[38] Riener, K.D. and Soenen, L. (1997) Analyzing Changes in Credit Policy in an International Environment. Managerial Finance, 23, 34-46.

https://doi.org/10.1108/eb018619

[39] Giddy, I.H. (1976) An Integrated Theory of Exchange Rate Equilibrium. The Journal of Financial and Quantitative Analysis, 11, 883-892. https://doi.org/10.2307/2330587

[40] Solnik, B.H. and Grall, J. (1975) Eurobonds: Determinants of the Demand for Capital and the International Interest Rates Structure. Journal of Bank Research, 2128-2230.

[41] Constantinides, G.M. (1984) Optimal Stock Trading with Personal Taxes: Implications for Prices and the Abnormal January Returns. Journal of Financial Economics, 13, 65-89. https://doi.org/10.1016/0304-405X(84)90032-1

[42] Kraizberg, E. (1992) Valuing Depreciable Assets. Journal of Accounting Auditing and Finance, 8, 115-136. https://doi.org/10.1177/0148558X9300800201 


\section{Appendix: Proof of the after Tax IRP (4)}

A tax payer in country $i$ wishes to have one unit of the currency of county $j$ in one period. The tax payer can purchase now $\frac{1}{1+r_{j}\left(1-\tau_{r j}\right)}$ of the foreign currency at the spot rate of $F_{i j}$ and invest the foreign currency in a riskless debt in country $j$. In one period, after paying the continuously payable taxes ${ }^{5}$ in country $j$, the tax payer will end up exactly with one unit of the currency of country $j$.

Alternatively the tax payer can purchase a forward contract in his own country to purchase one unit of the currency of country $j$ in one period in exchange for $E F_{i j}$ units of own country currency. Simultaneously, the tax payer invests the following sum in own country riskless debt (and in own currency and continuously pays taxes):

$$
\frac{E F_{i j}}{1+r_{i}\left(1-\tau_{r i}\right)}-\left(E F_{i j}-F_{i j}\right) \tau_{g i}
$$

The first term reflects domestic taxes on interest, and the second term reflects capital gain/loss on the change in the value of the foreign currency, payable upon realization as capital gain/loss tax in own country. This way the taxpayer will end up with exactly one unit of foreign currency.

Since the two alternatives are riskless and identical, avoiding arbitrage opportunities yields an equality:

$$
F_{i j} \frac{1}{1+r_{j}\left(1-\tau_{r j}\right)}=\frac{E F_{i j}}{1+r_{i}\left(1-\tau_{r i}\right)}-\left(E F_{i j}-F_{i j}\right) \tau_{g i}
$$

Rearranging (2) yields the after tax IRP:

$$
E F_{i j}=F_{i j} \frac{1+r_{i}\left(1-\tau_{r i}\right)}{\left[1+r_{j}\left(1-\tau_{r j}\right)\right]\left[1-\tau_{g i}\left(1+r_{i}\left(1-\tau_{r i}\right)\right)\right]}
$$

Keeping in mind the assumptions: 1) short and long term capital gain/loss are identically taxed and 2) in the long run the forward price is equal to the expected exchange rate with zero mean deviations.

${ }^{5}$ In some countries, such as the US, the taxes are payable quarterly. 